\title{
Toll-Like Receptor 2 Senses Hepatitis C Virus Core Protein but Not Infectious Viral Particles
}

\author{
Marco Hoffmann ${ }^{a}$ Mirjam B. Zeise ${ }^{c, d} \quad$ Nikolaus Jilga ${ }^{a}$ Glaucia Paranhos-Baccalà ${ }^{f}$ \\ Françoise Stoll-Keller ${ }^{c, d}$ Takaji Wakitag ${ }^{g}$ Peter Hafkemeyer ${ }^{a}$ Hubert E. Blum ${ }^{a}$ \\ Heidi Barth $^{a}$ Philipp Henneke ${ }^{b}$ Thomas F. Baumert ${ }^{a}$ c-e \\ ${ }^{a}$ Department of Medicine II and ${ }^{b}$ Center for Pediatrics and Adolescent Medicine, University of Freiburg, Germany; \\ 'Inserm, U748, d Université de Strasbourg and 'Service d'Hépatogastroentérologie, Hôpitaux Universitaires de \\ Strasbourg, Strasbourg, and fEmerging Pathogens Department, bioMérieux SA CERVI, Lyon, France; \\ gDepartment of Virology II, National Institute of Infectious Diseases, Tokyo, Japan
}

\section{Key Words}

Core protein $\cdot$ Hepatitis $\mathrm{C}$ virus $\cdot$ Toll-like receptors

\section{Abstract}

Toll-like receptors (TLRs) are pathogen recognition molecules activating the innate immune system. Cell surface expressed TLRs, such as TLR2 and TLR4, have been shown to play an important role in human host defenses against viruses through sensing of viral structural proteins. In this study, we aimed to elucidate whether TLR2 and TLR4 participate in inducing antiviral immunity against hepatitis $\mathrm{C}$ virus $(\mathrm{HCV})$ by sensing viral structural proteins. We studied TLR2 and TLR4 activation by cell culture-derived infectious virions and serum-derived virions in comparison to purified recombinant HCV structural proteins and enveloped viruslike particles. Incubation of TLR2 or TLR4 transfected cell lines with recombinant core protein resulted in activation of TLR2-dependent signaling. In contrast, neither infectious virions nor enveloped HCV-like particles triggered TLR2 and TLR4 signaling. These findings suggest that monomeric HCV core protein but not intact infectious particles are sensed by
TLR2. Impairment of interaction between TLR and the core in infectious viral particles may contribute to escape from innate antiviral immune responses.

Copyright $\odot 2009$ S. Karger AG, Basel

\section{Introduction}

Hepatitis $\mathrm{C}$ virus (HCV) is a major cause of hepatitis worldwide. The majority of HCV infected individuals develop chronic hepatitis that may progress to liver cirrhosis and hepatocellular carcinoma. Treatment options for chronic HCV infection are limited and a vaccine to prevent $\mathrm{HCV}$ infection is not available. HCV has been classified in a separate genus (Hepacivirus) of the Flaviviridae family. The virion contains a positive-stranded RNA genome of approximately $9.6 \mathrm{~kb}$ that is translated into a single polyprotein of about 3,000 amino acids. Processing

Marco Hoffmann and Mirjam B. Zeisel contributed equally to this work. Philipp Henneke and Thomas F. Baumert contributed equally to this work.

\section{KARGER \\ Fax +4161306 1234 \\ E-Mail karger@karger.ch}

www.karger.com
(C) 2009 S. Karger AG, Basel

$1662-811 X / 09 / 0015-0446 \$ 26.00 / 0$

Accessible online at:

www.karger.com/jin
Prof. Thomas F. Baumert

Inserm Unité 748, Université de Strasbourg

3 Rue Koeberlé

FR-67000 Strasbourg (France)

Tel. +33 3902437 03, Fax. +33 3902437 10, E-Mail Thomas.Baumert@unistra.fr 
of the polyprotein occurs by a combination of host and viral proteases. The HCV structural proteins comprise the putative nucleocapsid or core protein and the 2 envelope glycoproteins E1 and E2 [1].

Toll-like receptors (TLRs) are transmembrane pathogen recognition receptors that activate the innate immune system. To date, 10 complete members of the TLR family are expressed in humans (TLRs 1-10). Most of them are predominantly expressed on the cell surface (TLRs 1, 2, 4-6 and 10) to sense extracellular pathogenassociated molecular patterns, such as lipoproteins (TLR2 ligand) and lipopolysaccharide (LPS, TLR4 ligand). In contrast, TLRs 3 and 7-9 are located in intracellular compartments. Recognition of pathogen-associated molecular patterns by TLRs induces the activation of genes important for an effective host defense. Stimulation of TLR signaling pathways by ligand-induced multimerization leads to the recruitment of several intracellular adaptor molecules and kinases, resulting in the activation of nuclear factor $\kappa \mathrm{B}(\mathrm{NF}-\kappa \mathrm{B})$, cytokine secretion and expression of co-stimulatory molecules [2].

It has been well documented that intracellular TLRs are involved in recognition of viral nucleotides and induction of antiviral interferon responses [reviewed in 2]. Cell surface expressed TLRs, such as TLR2 and TLR4, play an important role in human host defenses against viruses, such as herpes simplex virus, cytomegalovirus, respiratory syncytial virus and measles virus [3].

HCV proteins have been shown to up-regulate TLR2 and TLR4 expression on Raji cells and peripheral blood mononuclear cells, thereby modulating their proinflammatory responses $[4,5]$. Moreover, recent studies have provided evidence that the HCV core can activate TLR2 $[6,7]$. The authors used recombinant monomeric C-terminal truncated core protein and full-length core protein fused to $\beta$-galactosidase to stimulate TLR2-expressing HEK cells and mouse macrophages. However, the significance of an interaction between recombinant HCV core protein and TLR 2 for the induction of innate immune responses to viral infection is unknown. Studies on HCVhost interaction had been hampered for a long time by the lack of an efficient tissue culture model for HCV infection. Thus, alternative model systems, such as recombinant proteins, enveloped HCV-like particles $[8,9]$ and pseudotype particles [10] have been developed to study defined aspects of the HCV life cycle [for review see 11]. A major breakthrough for the study of HCV-host cell interaction was the recent establishment of an efficient cell culture system for HCV [12-14]. This model system now allows study of the interaction between authentic infec- tious viral particles and human target cells. To address the role of TLR2 and TLR4 for sensing assembled HCV particles and the impact of this interaction for HCV pathogenesis, we studied TLR2 and TLR4 activation by cell-culture-derived infectious virions ( $\mathrm{HCVcc}$ ) and serum-derived virions in comparison to purified recombinant $\mathrm{HCV}$ structural proteins and enveloped virus-like particles.

\section{Materials and Methods}

\section{Reagents}

Recombinant HCV core fused to $\beta$-galactosidase, core aa 1119 and core aa 2-192 were from Biodesign and Austral Biologicals, respectively. Alternatively, core aa 1-119 (genotype 1a) fused to a His-tag was expressed in E. coli strain BL21 (DE3) and purified as described [15]. This protein preparation was free of endotoxin as tested by the Limulus assay. Recombinant HCV E1 and E2 (genotype $1 b$ ) have been described $[15,16]$. Mouse anti-core monoclonal antibody (mAb) has been described [8]. HCV-like particles were synthesized and purified from insect cells infected with recombinant baculoviruses containing the cDNA of the $\mathrm{HCV}$ structural proteins of HCV strain H77c (genotype 1a) as described [17]. HCV core protein within HCV-like particles was quantified as described [18].

\section{Cells}

CHO fibroblast cell lines stably transfected with a reporter construct that encodes for CD25 under transcriptional control of the human E selectin (ELAM) promoter, hygromycin resistance, human CD14 plus human Flag-tagged TLR2 or TLR4 have been described elsewhere [19-23]. Upon stimulation with LPS, TNF $\alpha$ or IL-1 $\beta$, the ELAM promoter drives the expression of surface $\mathrm{CD} 25$ as a result of NF- $\kappa \mathrm{B}$ translocation. TLR2 and TLR4 transfected CHO cells were cultured in Ham's F12 medium (BioWhittaker) supplemented with 10\% FBS (HyClone), 2 m M L-glutamine, $100 \mathrm{U} / \mathrm{ml}$ penicillin, $100 \mu \mathrm{g} / \mathrm{ml}$ streptomycin, $400 \mathrm{U} / \mathrm{ml}$ hygromycin B (Calbiochem) and $1 \mathrm{mg} / \mathrm{ml} \mathrm{G} 418$ (Invitrogen). Human epithelial kidney (HEK) 293 cells (ATCC) stably transfected with human TLR2 (HEK/TLR2) or human TLR4-YFP and human MD-2 (HEK/TLR4) have been described previously [24]. HEK293 cells were maintained by serial passage in Dulbecco's Modified Eagle's Medium (DMEM) supplemented with 10\% FBS, L-glutamine, ciprofloxacin and G418. Isolation and maintenance of primary human hepatocytes has been described [25]. Huh-7.5 cells have been previously described [26]. Cells were maintained in DMEM supplemented with $10 \%$ FBS (PAN-Biotech), $100 \mathrm{U} / \mathrm{ml}$ penicillin, 100 $\mu \mathrm{g} / \mathrm{ml}$ streptomycin and non-essential amino acids.

Generation of HCVcc and Infection of Huh7.5.

Plasmids encoding the full-length HCV JFH1 cDNA as well as the E1 and E2 deleted mutant JFH1/DE1E2 have been described [12]. In vitro HCV RNA synthesis [27] and RNA transfection was carried out as described $[14,28]$. Supernantants from HCV RNA transfected Huh7.5 cells were collected and concentrated as described [12]. For detection of HCV proteins in transfected cells, proteins were separated by SDS-PAGE, followed by immunoblot- 
ting with mouse anti-core $\mathrm{mAb}$ and sheep peroxidase-labeled anti-mouse polyclonal antibodies. $5 \times 10^{4}$ naïve cells/well were seeded $24 \mathrm{~h}$ prior to infection experiments in 12-well tissue culture plates. Cells were infected for $3 \mathrm{~h}$ at $37^{\circ} \mathrm{C}$ with $\mathrm{HCVcc}$ and then incubated with complete medium for the indicated times. Cells were then washed with ice-cold PBS, total RNA extracted and HCV RNA quantitated using Versant HCV-RNA 3.0 Assay (bDNA; Bayer Corp. Diagnostic). Immunofluorescence was performed $48 \mathrm{~h}$ after infection using mouse anti-core $\mathrm{mAb}$ and goat Cy3-labeled anti-mouse polyclonal anitbodies (Jackson Immunoresearch). Nuclear staining was performed using DAPI (4',6diamidino-2-phenylindole).

Analysis of NF- $\kappa B$-Dependent CD25 Cell Surface Expression on CHO 3E10, 3E10/TLR2 and 3E10/TLR4 Cells

$7 \times 10^{4}$ cells/well were seeded $24 \mathrm{~h}$ prior to experiments in 24 well tissue culture plates. Cells were washed 3 times with PBS and then stimulated for $18 \mathrm{~h}$ with medium, LPS, peptidoglycan (PG), recombinant $\mathrm{HCV}$ proteins, $\mathrm{HCV}$-like particles or $\mathrm{HCVcc}$, detached from the plastic with trypsin/EDTA, and examined by flow cytometry (Facscalibur and CellQuest 3.11 software, Becton Dickinson) for the presence of surface CD25 as described [20-23].

\section{Luciferase Reporter Assays for NF- $\kappa B$ Activation}

HEK293 cells that stably expressed human TLR2 or TLR4 as well as wild-type HEK cells were seeded into 96-well tissue culture plates at a density of $2 \times 10^{4}$ cells/well. The following day, HEK293 cells were transiently transfected with a luciferase reporter gene using Fugene (Roche) according to the manufacturer's instructions. To assess NF- $\kappa \mathrm{B}$ activation, a reporter gene consisting of an E-selectin promoter driving a firefly luciferase gene (pELAM.luc) was used. Huh7.5 cells were seeded into 96-well tissue culture plates at a density of $2 \times 10^{4}$ cells/well. The following day, cells were transfected with pELAM.luc or cotransfected with pELAM.luc and human TLR2 ${ }^{\text {FLAG }}$. Twenty-four hours after transfection, HEK293 and Huh7.5 cells were washed and then challenged for $18 \mathrm{~h}$ and $5 \mathrm{~h}$, respectively, with medium, LPS, PG, recombinant HCV proteins, $\mathrm{HCV}$-like particles or HCVcc at the indicated concentrations. Cells were then lysed and reporter gene activity was measured using a plate reader luminometer (Berthold Detection Systems).

\section{RT-PCR for TLRs}

RNA from primary hepatocytes and Huh7.5 hepatoma cells was extracted with TRI reagent (Sigma) and transcribed into cDNA with the Access Quick RT-PCR kit (Promega). The sequences of the employed primer pairs for PCR were $5^{\prime}$-AGGCTGCATTCCCAAGACACT-3' and 5'-AGCCAGGCCCACATCATTTT-3' for TLR2 and 5'-TGCGGGTTCTACATCAAA-3' and 5'-CCATCCGAAATTATAAGAAAAGTC-3' for TLR4.

\section{Results}

\section{Interaction of HCV with TLR2 and TLR4 on HCV Target Cells}

It has been shown that $\mathrm{HCV}$ proteins may interact with TLR2 on monocytes/macrophages and trigger a proinflammatory immune reponse $[6,7]$. In view of the potential role of TLRs in the recognition of HCV by human hepatocytes, we studied whether TLR2 and TLR4 are expressed both in primary human hepatocytes (the natural target cell for HCV infection) and the human hepatoma cell line Huh7.5 (a cell line susceptible to infection with recombinant cell culture-derived HCV). Using TLR2 and TLR4-specific RT-PCR we demonstrate that TLR2 and TLR4 mRNA can be easily detected in primary human hepatocytes and Huh7.5 cells (fig. 1). These data suggest that TLR 2 and TLR 4 are expressed not only in antigen-presenting cells but also in primary human hepatocytes - the key target cells of HCV infection.

\section{TLR Activation by HCV Structural Proteins}

To study whether the interaction of the viral envelope, the viral nucleocapsid or enveloped particles with TLR2 and TLR4 results in TLR signaling, we used 2 well-established model systems allowing specific and reliable determination of the activation of TLR2- and/or TLR4-dependent signaling: stably transfected $\mathrm{CHO}$ cells expressing human TLR2 and/or TLR4 on their cell surface and a reporter gene allowing detecting ligand-induced TLR activation [23] as well as TLR2- or TLR4-transfected HEK293 cells [24].

As shown in figure 2a, the TLR2 ligand PG and recombinant C-terminally truncated core protein $(0.1-10 \mu \mathrm{g} /$ $\mathrm{ml}$ ) activated TLR2 transfected CHO cells in a dose-dependent fashion, whereas heat inactivated core $(10 \mu \mathrm{g} /$ $\mathrm{ml}$ ) had no effect (fig. 2a). In contrast, enveloped HCVlike particles (containing $1-10 \mu \mathrm{g} / \mathrm{ml}$ core protein) or recombinant envelope proteins E1 and E2 $(10 \mu \mathrm{g} / \mathrm{ml}) \mathrm{did}$ not result in transcriptional activation of TLR2-transfected $\mathrm{CHO}$ cells (fig. 2a). Similar results were obtained with HEK293 transfected with human TLR2 (fig. 2c). As shown in figure $2 c$, whereas recombinant C-terminally truncated core (aa 1-119) or full-length core (aa 2-192) protein fused to $\beta$-galactosidase resulted in TLR2 activation as demonstrated by induction of NF- $\kappa \mathrm{B}$ luciferase reporter gene expression, enveloped HCV-like particles containing comparable amounts of core protein did not induce TLR2 activation (fig. 2c).

Next, we used TLR4 expressing cells to study whether enveloped HCV-like particles induce TLR4 signaling. Our results show that neither HCV core protein $(10 \mu \mathrm{g} /$ $\mathrm{ml})$ nor HCV envelope proteins E1 and E2 $(10 \mu \mathrm{g} / \mathrm{ml})$ trigger TLR4 activation in transfected CHO and HEK293 cells (fig. 2b, d). Moreover, enveloped HCV-like particles were not able to stimulate TLR4 signaling (fig. 2b, d).

Taken together, these results suggest that HCV core protein induces NF- $\kappa \mathrm{B}$ activation through interaction 
Fig. 1. TLR2 and TLR4 are expressed in human hepatocytes and hepatoma cells. a RNA was extracted from primary human hepatocytes (PHH) and Huh7.5 human hepatoma cells and RT-PCR was performed for expression of TLR2 and TLR4 (lanes 1 and 4). HEK-cells stably transfected with human TLR2 or TLR4 (lanes 2 and 5) or RNA from PHH or Huh7.5 cells that had not been transcribed into cDNA (Mock; lanes 3 and 6) were used as controls. b RNA was extracted from HEK/ TLR2 and HEK/TLR4 cells and RT-PCR was performed for expression of TLR 2 and TLR4.
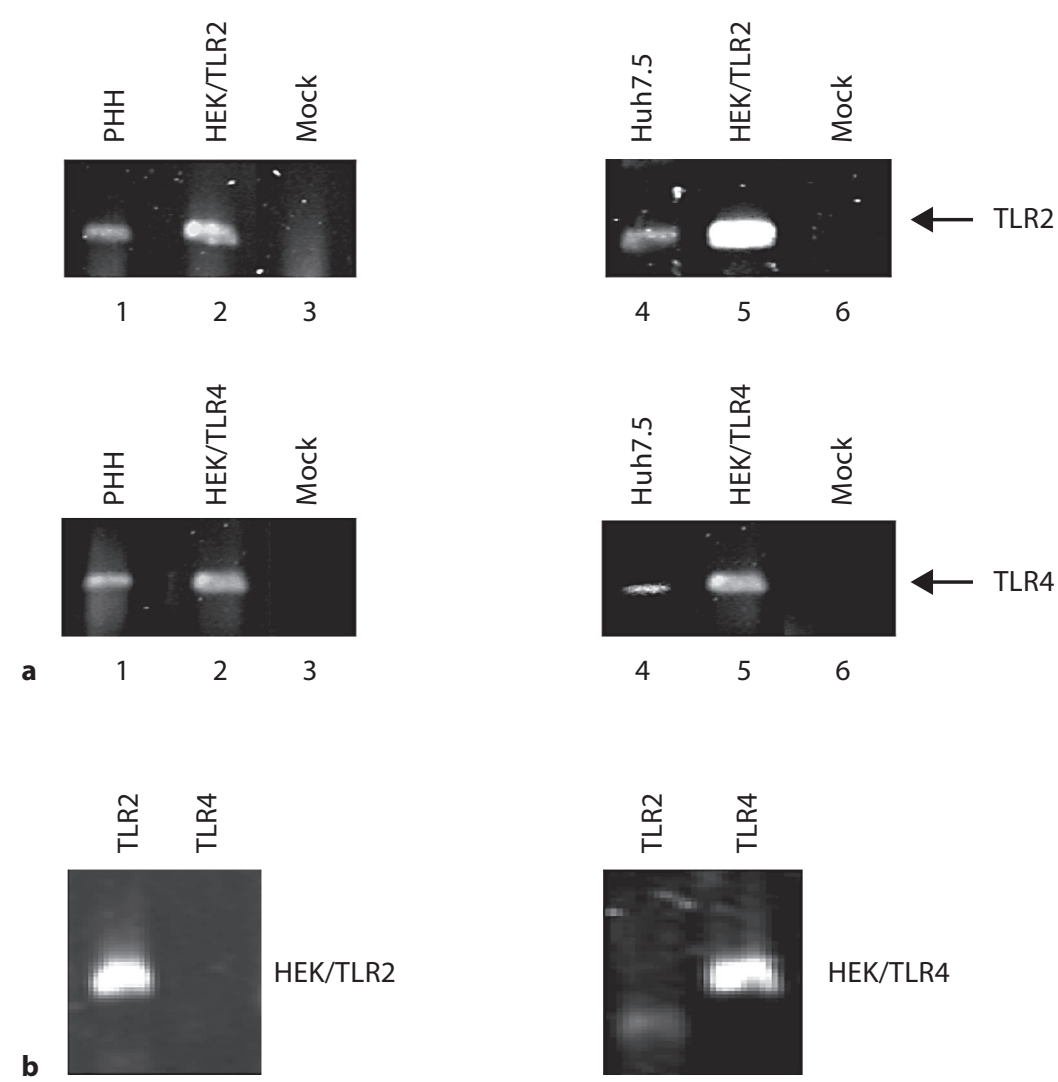

with TLR2, but not TLR4. In contrast, neither recombinant envelope glycoproteins nor enveloped HCV-like particles containing an intact nucleocapsid [29] induced TLR2-dependent signaling pathways.

\section{TLR Activation by Cell Culture-Derived Infectious HCV}

To determine the impact of these findings for the interaction of authentic infectious HCV with TLRs, we produced recombinant infectious virions (HCVcc) derived from the HCV JFH1 strain in human Huh7.5 hepatoma cells (fig. $3 \mathrm{a}-\mathrm{c}$ ) using the recently established tissue culture system for HCV infection [12-14]. The infectivity of produced virions was confirmed by detection of $\mathrm{HCV}$ RNA and HCV proteins in infected Huh7.5 cells using HCV-specific RT-PCR and immunofluorescence (fig. 3b, c). We then added HCVcc (tested for infectivity as described in fig. $3 \mathrm{~b}, \mathrm{c})$ to stably transfected $\mathrm{CHO}$ and HEK293 reporter cells in various concentrations (fig. 3d).
Our results show that infectious $\mathrm{HCVcc}$, at concentrations able to infect human hepatoma Huh7.5 cells (fig. 3b, c), did not significantly activate TLR2 or TLR4 depending signaling pathways in TLR2 and TLR4 expressing CHO and HEK293 cells when compared to non-infectious supernatants from envelope protein-deficient JFH1/ $\Delta$ E1E2 RNA transfected Huh7.5 cells (fig. 3d). HCV RNA levels $\left(10^{5}-10^{7} \mathrm{GE} / \mathrm{ml}\right)$ in $\mathrm{HCV} c c$ preparations were in a similar range as the typical viral load in patients with chronic HCV infection. HCV cc core concentrations in HCVcc preparations $\left(10^{5}-10^{7} \mathrm{GE} / \mathrm{ml}\right)$ typically range in between $150 \mathrm{pg} / \mathrm{ml}$ and $33 \mathrm{ng} / \mathrm{ml}$ core protein [Pietschmann T., pers. commun.; 12, 30], which is in a similar range as core $\mathrm{HCV}$ concentrations measured in serum of $\mathrm{HCV}$-infected patients (ranging typically from $20 \mathrm{pg} / \mathrm{ml}$ to $5 \mathrm{ng} / \mathrm{ml}$ ) [31, 32].

To confirm the results obtained with recombinant cell culture-derived HCVcc, we incubated reporter cell lines with serum-derived HCV from chronically infected pa- 


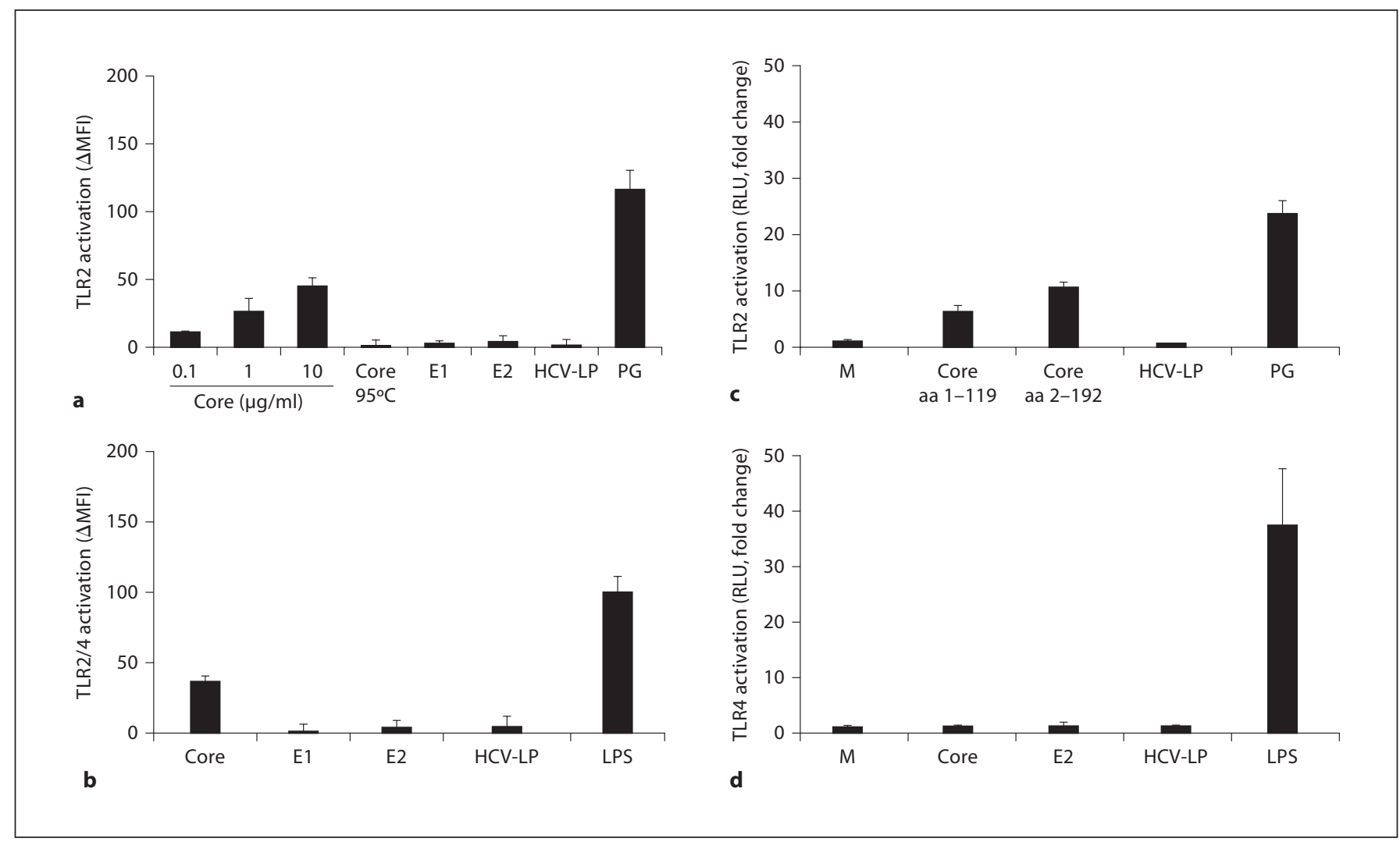

Fig. 2. TLR-activation by HCV structural proteins. a, b TLR-activation by HCV structural proteins in CHO cells. 3E10/TLR2 cells, stably transfected with the cDNA for human TLR2 (a) or TLR 2 and TLR4 (b) and an NFKB-dependent reporter gene, were incubated for $18 \mathrm{~h}$ with indicated concentrations of recombinant $\mathrm{HCV}$ core protein, $10 \mu \mathrm{g} / \mathrm{ml}$ heat inactivated recombinant $\mathrm{HCV}$ core protein (Core $95^{\circ} \mathrm{C}$ ), recombinant $\mathrm{HCV}$ envelope glycoproteins (E1 and E2) and enveloped HCV-like particles (containing $1-10 \mu \mathrm{g} / \mathrm{ml}$ core protein). Incubation of cells with PG from Staphylococcus aureus $(10 \mu \mathrm{g} / \mathrm{ml})$ or LPS from Escherichia coli O26:B6 $(1 \mu \mathrm{g} / \mathrm{ml})$ served as positive controls. TLR activation was detected by surface expression of CD25 reporter using FACS and FITC-labeled anti-CD25 antibody. Mean values \pm SD of net mean fluo-

tients. Similar to findings with cell culture-derived HCVcc, we neither observed a TLR2 nor TLR4 activation following incubation of reporter cell lines with native HCV (data not shown). These data demonstrate that in contrast to efficient TLR2 sensing of core protein preparations, neither recombinant nor serum-derived infectious virions are efficiently sensed by TLR2. Taken together, these results suggest that monomeric core protein, but not core as part of authentic infectious virions induces TLR2 signaling.

rescence intensity $(\triangle \mathrm{MFI})$ of 3 independent experiments are shown. c, d TLR-activation by HCV structural proteins in HEK293 cells. HEK293 cells, transiently transfected with pELAM.luc and expressing human TLR2 (c) or TLR4 (d), were incubated for $18 \mathrm{~h}$ with $10 \mu \mathrm{g} / \mathrm{ml}$ recombinant full-length (aa 2-192) and truncated (aa 1-119) core proteins as well as enveloped HCV-like particles (containing 1-10 $\mu \mathrm{g} / \mathrm{ml}$ core protein). Incubation of cells with complete medium (M), PG $(10 \mu \mathrm{g} / \mathrm{ml})$ or LPS $(1 \mu \mathrm{g} / \mathrm{ml})$ served as negative and positive controls, respectively. TLR2 activation was detected by luciferase activity corresponding to the expression of reporter plasmid pELAM.luc. Mean values \pm SD of fold change in relative light units (RLU) of 3 independent experiments are shown.

\section{Discussion}

Our data indicate that HCV core protein is sensed by TLR2. In contrast, neither recombinant nor serum-derived infectious HCV resulted in efficient activation of TLR2 signaling. Although target cell lines including human dendritic cells [18] and hepatocytes express TLR2 at significant levels (fig. 1), our results indicate that $\mathrm{HCV}$ core sensing by TLR 2 appears to be absent in enveloped viral particles. 


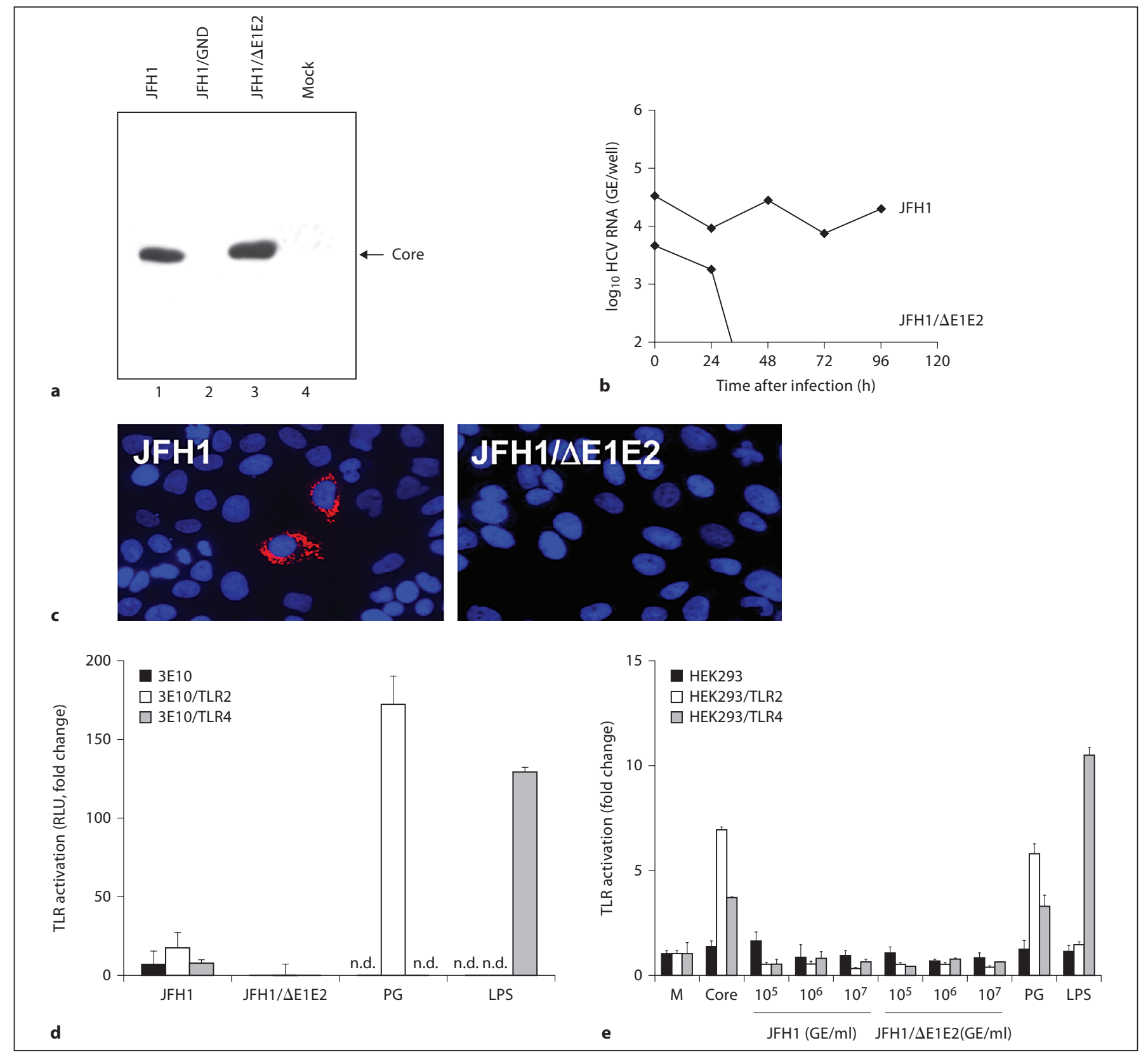

Fig. 3. TLR-activation by HCVcc. a Production of HCVcc and control supernatants by transfection of Huh7.5 cells with JFH1, JFH1/ GND and JFH1/DE1E2 RNA. Huh7.5 cells were lysed $96 \mathrm{~h}$ after electroporation of full-length JFH1, JFH1/GND containing a mutation in the RNA polymerase or envelope-protein-deficient JFH1/ $\triangle$ E1E2 HCV RNA. Proteins were separated by SDS-PAGE, followed by immunoblotting with anti-core monoclonal antibody. b HCVcc-infection of Huh7.5 cells assessed by RT-PCR of intracellular HCV RNA. Huh7.5 cells were incubated for $3 \mathrm{~h}$ at $37^{\circ} \mathrm{C}$ with $\mathrm{HCVCc}$ at $10^{7}$ genome equivalents/ml (GE/ml; JFH1 or JFH1/ $\Delta$ E1E2) and subsequently incubated for $24,48,72$ and $96 \mathrm{~h}$ at $37^{\circ} \mathrm{C}$ with Huh7.5 medium. Intracellular HCV RNA was quantified. c Analysis of HCVcc-infection of Huh7.5 cells by immunofluorescence. Huh7.5 cells were incubated for $3 \mathrm{~h}$ at $37^{\circ} \mathrm{C}$ with $\mathrm{HCVcc}$ at

$10^{7} \mathrm{GE} / \mathrm{ml}$ (JFH1 or JFH1/ $\left.\Delta \mathrm{E} 1 \mathrm{E} 2\right)$ and subsequently incubated for $48 \mathrm{~h}$ at $37^{\circ} \mathrm{C}$ with Huh7.5 medium. HCV core protein expression was detected using an anti-core monoclonal antibody and a Cy3conjugated anti-mouse IgG antibody (red fluorescence). Nuclear staining was performed using DAPI (4',6-diamidino-2-phenylindole; blue fluorescence). $\mathbf{d}$ TLR-activation by HCVcc-as produced and characterized in a-c - in transfected CHO and HEK293 cells. $\mathrm{CHO}$ cells were incubated with HCVcc at $10^{7} \mathrm{GE} / \mathrm{ml}$ and HEK293 with $\mathrm{HCVcc}$ at $10^{5}, 10^{6}$ and $10^{7} \mathrm{GE} / \mathrm{ml}$ (corresponding to approximately $150 \mathrm{pg} / \mathrm{ml}$ to $33 \mathrm{ng} / \mathrm{ml}$ core protein) for $18 \mathrm{~h}$ at $37^{\circ} \mathrm{C}$. Incubation of cells with complete medium (M), PG $(10 \mu \mathrm{g} / \mathrm{ml})$, LPS $(1 \mu \mathrm{g} / \mathrm{ml})$ or recombinant core protein $(10 \mu \mathrm{g} / \mathrm{ml})$ served as negative and positive controls, respectively. TLR-activation was determined as described in legend of figure 2. n.d. = Not determined. 
Since recombinant core proteins were able to induce TLR2 activation at concentrations as low as $0.1 \mu \mathrm{g} / \mathrm{ml}$ (fig. 2b) and enveloped HCV-like particles did not activate TLR2 signaling at high $\mathrm{HCV}$-like particle core concentrations (up to $10 \mu \mathrm{g} / \mathrm{ml}$ ), it is unlikely that the lack of HCV-like particle-induced TLR2 activation was due to a dose-dependent effect. Moreover, as HCV RNA $\left(10^{5}-10^{7}\right.$ $\mathrm{GE} / \mathrm{ml}$ ) and core (approx. $150 \mathrm{pg} / \mathrm{ml}-33 \mathrm{ng} / \mathrm{ml}$ ) levels in supernatants from Huh7.5 cells $[12,30]$ were in the same range as HCV RNA (ranging typically from $10^{5}$ to $10^{7}$ $\mathrm{GE} / \mathrm{ml}$ ) and core (ranging typically from $20 \mathrm{pg} / \mathrm{ml}$ to $5 \mathrm{ng} / \mathrm{ml}$ ) levels in plasma of HCV-infected patients [3134], it is unlikely that the quantity of infectious virions was not sufficient to detect physiological relevant $\mathrm{HCV}$ TLR2 activation.

$\mathrm{HCV}$ is a virus prone to persistence that has developed different strategies to evade the host's innate and adaptive immune responses. HCV has been shown to interfere with innate antiviral defenses through multiple mechanisms; for example, core protein induces expression of SOCS-3 which suppresses Jak-STAT signaling, and NS3/4A protease is an antagonist of IRF-3 activation and interferon- $\beta$ expression by blocking RIG-I and TLR3 signaling [reviewed in 35,36 ]. The fact that in contrast to purified core, enveloped HCV-like particles and infectious virions were less efficient in activating TLR2 suggests that multimeric core protein as part of an enveloped nucleocapsid may escape the host's innate immune responses. Our results indicate that 2 mechanisms may explain this escape: (1) in intact viral particles, the core protein may adopt a conformation that might not be recognized by TLR2; (2) the envelope glycoproteins in infectious virions impair HCV core-sensing by TLR2.

The first hypothesis - conformation-dependent sensing of core protein - is supported by the finding that denaturation of monomeric core protein by heat treatment completely abolished TLR2 sensing (fig. 2). Furthermore, this hypothesis is supported by the fact that preparations of partially purified HCV-like particles have been shown to contain de-enveloped core-containing structures [29] and still are not able to induce TLR signaling (fig. 2). In addition, supernatants from envelope protein-deficient JFH1/DE1E2 RNA transfected Huh7.5 cells that also contain core protein [as shown in 12] but not infectious enveloped particles (fig. 4) were inefficient in activating TLR signaling. Taken together, these findings suggest that multimeric core protein as part of a nucleocapsid is less efficient in TLR2 activation than monomeric core protein.
The second hypothesis - impairment of core sensing by the HCV envelope - is supported by the finding that recombinant envelope glycoproteins and enveloped recombinant and patient-derived HCV were not able to induce TLR2 activation (fig. 2). This hypothesis is further supported by the finding that TLR2- and/or TLR4-transfected $\mathrm{CHO}$ cells did not bind recombinant envelope proteins or enveloped HCV-like particles (data not shown) and that interaction of enveloped HCV-like particles with dendritic cells is independent of cell surface TLR2 [18].

What is the impact of these findings for sensing of HCV core protein by TLR2 in vivo? HCV entry into host cells has been demonstrated to be a complex process involving several binding and entry factors ultimately leading to decapsidation of the virus in endosomal compartments and release of viral RNA into the cytoplasm. Since monomeric core protein, but not core as part of a nucleocapsid or subviral particle, interacts with TLR2, it is conceivable that HCV particles are not sensed by cell surface-expressed TLR2 during binding and early entry steps. In vivo, TLR2 sensing and activation will most likely be triggered by core protein that results from degraded nucleocapsids or unassembled core protein released from disintegrated infected hepatocytes at distinct sites of the infected host. Since recent studies demonstrate evidence for intracellular expression of TLRs [37], it is also conceivable that core-TLR2 interaction and activation may occur following viral uncoating or production of monomeric protein in an intracellular compartment.

In summary, our data demonstrate that only monomeric core protein - and not infectious viral particles are sensed by TLR2. Impairment of core-TLR interaction in infectious particles may contribute to escape from innate antiviral immune responses and facilitate persistence of $\mathrm{HCV}$ infection.

\section{Acknowledgments}

We thank Bettina Gissler, Andrea Müller and Inga Möller for excellent technical assistance, Charles M. Rice (Rockefeller University, New York, N.Y., USA) for providing Huh7.5 cells, H.B. Greenberg (Stanford University, Palo Alto, Calif., USA) for mouse anti-core antibodies, Douglas Golenbock (University of Massachusetts, Worcester, Mass., USA) for the gift of stably transfected CHO cell lines expressing TLR2 and TLR4, as well as Daniel Jaeck (Hôpitaux Universitaires de Strasbourg, France) and Cathy Royer (Inserm U748, Strasbourg, France) for providing primary human hepatocytes. The authors would like to thank Thomas Pietschmann (Twincore - Department of Experimental Virology, Center 
for Experimental and Clinical Infection Research, Hannover, Germany) for helpful discussions. This work was supported by grants from the European Union (QLK-2-CT-2002-01329) and Virgil Network of Excellence (LSHM-CT-2004-503359 to T.F.B.), the Else-Kröner-Fresenius Stiftung (P17/07//A83/06 to T.F.B. and H.B.), Bad Homburg, Germany, Deutsche Forschungsgemeinschaft, Bonn, Germany (Ba1417/11-2, to T.F.B. and He3127/2-3 and 3127/3-1 to P.H.), Institut National de la Santé et de la Recherche Médicale (Inserm), Paris, France (to T.F.B.), the chair of the excellence program of the Agence Nationale de la Recherche, Paris, France (ANR-05-CEXC-008 to T.F.B.) and Agence Nationale de la Recherche sur le SIDA et les Hépatites Virales, Paris, France (ANRS grant No. 06221 to T.F.B).

\section{References}

1 Lindenbach BD, Thiel HJ, Rice CM: Flaviviridae: the viruses and their replication; in Knipe DM, Howley PM (eds): Fields Virology. Philadelphia, Lippincott-Raven, 2007, pp 1101-1152.

-2 Akira S, Uematsu S, Takeuchi O: Pathogen recognition and innate immunity. Cell 2006; 124:783-801.

3 Boehme KW, Compton T: Innate sensing of viruses by Toll-like receptors. J Virol 2004; 78:7867-7873.

4 Machida K, Cheng KT, Sung VM, Levine AM, Foung S, Lai MM: Hepatitis C virus induces toll-like receptor 4 expression, leading to enhanced production of beta interferon and interleukin-6. J Virol 2006;80:866-874.

5 Feldmann G, Nischalke HD, Nattermann J, Banas B, Berg T, Teschendorf C, Schmiegel W, Duhrsen U, Halangk J, Iwan A, Sauerbruch T, Caselmann WH, Spengler U: Induction of interleukin- 6 by hepatitis $\mathrm{C}$ virus core protein in hepatitis $\mathrm{C}$-associated mixed cryoglobulinemia and B-cell non-Hodgkin's lymphoma. Clin Cancer Res 2006;12:44914498.

6 Dolganiuc A, Oak S, Kodys K, Golenbock DT, Finberg RW, Kurt-Jones E, Szabo G: Hepatitis $\mathrm{C}$ core and nonstructural 3 proteins trigger Toll-like receptor 2-mediated pathways and inflammatory activation. Gastroenterology 2004;127:1513-1524.

7 Dolganiuc A, Chang S, Kodys K, Mandrekar P, Bakis G, Cormier M, Szabo G: Hepatitis C virus $(\mathrm{HCV})$ core protein-induced, monocyte-mediated mechanisms of reduced IFNalpha and plasmacytoid dendritic cell loss in chronic HCV infection. J Immunol 2006; 177:6758-6768.

8 Baumert TF, Ito S, Wong DT, Liang TJ: Hepatitis $\mathrm{C}$ virus structural proteins assemble into viruslike particles in insect cells. J Virol 1998;72:3827-3836.

-9 Barth H, Schnober EK, Neumann-Haefelin C, Thumann C, Zeisel MB, Diepolder HM, Hu Z, Liang TJ, Blum HE, Thimme R, Lambotin M, Baumert TF: Scavenger receptor class $B$ is required for hepatitis $C$ virus uptake and cross-presentation by human dendritic cells. J Virol 2008;82:3466-3479.
10 Bartosch B, Dubuisson J, Cosset FL: Infectious hepatitis $C$ virus pseudo-particles containing functional E1-E2 envelope protein complexes. J Exp Med 2003;197:633-642.

11 Zeisel MB, Baumert TF: Production of infectious hepatitis $\mathrm{C}$ virus in tissue culture: a breakthrough for basic and applied research. J Hepatol 2006;44:436-439.

12 Wakita T, Pietschmann T, Kato T, Date T, Miyamoto M, Zhao Z, Murthy K, Habermann A, Krausslich HG, Mizokami M, Bartenschlager R, Liang TJ: Production of infectious hepatitis $C$ virus in tissue culture from a cloned viral genome. Nature medicine 2005;11:791-796.

13 Zhong J, Gastaminza P, Cheng G, Kapadia S, Kato T, Burton DR, Wieland SF, Uprichard SL, Wakita T, Chisari FV: Robust hepatitis C virus infection in vitro. Proc Natl Acad Sci USA 2005;102:9294-9299.

14 Lindenbach BD, Evans MJ, Syder AJ, Wolk B, Tellinghuisen TL, Liu CC, Maruyama T, Hynes RO, Burton DR, McKeating JA, Rice $\mathrm{CM}$ : Complete replication of hepatitis $\mathrm{C}$ virus in cell culture. Science 2005;309:623626.

15 Rollier CS, Paranhos-Baccala G, Verschoor EJ, Verstrepen BE, Drexhage JA, Fagrouch Z, Berland JL, Komurian-Pradel F, Duverger B, Himoudi N, Staib C, Meyr M, Whelan M, Whelan JA, Adams VC, Larrea E, Riezu JI, Lasarte JJ, Bartosch B, Cosset FL, Spaan WJ, Diepolder HM, Pape GR, Sutter G, Inchauspe G, Heeney JL: Vaccine-induced early control of hepatitis $\mathrm{C}$ virus infection in chimpanzees fails to impact on hepatic PD-1 and chronicity. Hepatology 2007;45:602-613.

16 Barth H, Schnober EK, Zhang F, Linhardt RJ, Depla E, Boson B, Cosset FL, Patel AH, Blum HE, Baumert TF: Viral and cellular determinants of the hepatitis $C$ virus envelope-heparan sulfate interaction. J Virol 2006;80: 10579-10590

17 Fang X, Zeisel MB, Wilpert J, Gissler B, Thimme R, Kreutz C, Maiwald T, Timmer J, Kern WV, Donauer J, Geyer M, Walz G, Depla E, von Weizsacker F, Blum HE, Baumert TF: Host cell responses induced by hepatitis C virus binding. Hepatology 2006;43:13261336.
18 Barth H, Ulsenheimer A, Pape GR, Diepolder HM, Hoffmann M, Neumann-Haefelin C, Thimme R, Henneke P, Klein R, Paranhos-Baccala G, Depla E, Liang TJ, Blum HE, Baumert TF: Uptake and presentation of hepatitis $\mathrm{C}$ virus-like particles by human dendritic cells. Blood 2005;105:3605-3614

19 Heine H, Kirschning CJ, Lien E, Monks BG, Rothe M, Golenbock DT: Cutting edge: cells that carry a null allele for Toll-like receptor 2 are capable of responding to endotoxin. J Immunol 1999;162:6971-6975.

-20 Lien E, Sellati TJ, Yoshimura A, Flo TH, Rawadi G, Finberg RW, Carroll JD, Espevik $\mathrm{T}$, Ingalls RR, Radolf JD, Golenbock DT: Toll-like receptor 2 functions as a pattern recognition receptor for diverse bacterial products. J Biol Chem 1999;274:3341933425.

21 Yoshimura A, Lien E, Ingalls RR, Tuomanen E, Dziarski R, Golenbock D: Cutting edge: recognition of Gram-positive bacterial cell wall components by the innate immune system occurs via toll-like receptor 2. J Immunol 1999;163:1-5.

-22 Delude RL, Yoshimura A, Ingalls RR, Golenbock DT: Construction of a lipopolysaccharide reporter cell line and its use in identifying mutants defective in endotoxin, but not TNF-alpha, signal transduction. J Immunol 1998;161:3001-3009.

23 Medvedev AE, Henneke P, Schromm A, Lien E, Ingalls R, Fenton MJ, Golenbock DT, Vogel SN: Induction of tolerance to lipopolysaccharide and mycobacterial components in chinese hamster ovary/CD14 cells is not affected by overexpression of Toll-like receptors 2 or 4. J Immunol 2001;167:2257-2267.

24 Latz E, Visintin A, Lien E, Fitzgerald KA, Monks BG, Kurt-Jones EA, Golenbock DT, Espevik T: Lipopolysaccharide rapidly traffics to and from the Golgi apparatus with the toll-like receptor 4-md-2-cd14 complex in a process that is distinct from the initiation of signal transduction. J Biol Chem 2002;277: 47834-47843.

25 Codran A, Royer C, Jaeck D, Bastien-Valle M, Baumert TF, Kieny MP, Pereira CA, Martin JP: Entry of hepatitis $C$ virus pseudotypes into primary human hepatocytes by clathrin-dependent endocytosis. J Gen Virol 2006;87:2583-2593. 
26 Blight KJ, McKeating JA, Rice CM: Highly permissive cell lines for subgenomic and genomic hepatitis $\mathrm{C}$ virus RNA replication. J Virol 2002;76:13001-13014.

- 27 Kato T, Date T, Miyamoto M, Furusaka A, Tokushige K, Mizokami M, Wakita T: Efficient replication of the genotype 2a hepatitis C virus subgenomic replicon. Gastroenterology 2003;125:1808-1817.

28 Zeisel MB, Koutsoudakis G, Schnober EK, Haberstroh A, Blum HE, Cosset F-L, Wakita T, Jaeck D, Doffoel M, Royer C, Soulier E, Schvoerer E, Schuster C, Stoll-Keller F, Bartenschlager R, Pietschmann T, Barth $\mathrm{H}$, Baumert TF: Scavenger receptor $\mathrm{BI}$ is a key host factor for hepatitis $\mathrm{C}$ virus infection required for an entry step closely linked to CD81. Hepatology 2007;46:1722-1731.

29 Maillard P, Krawczynski K, Nitkiewicz J, Bronnert C, Sidorkiewicz M, Gounon P, Dubuisson J, Faure G, Crainic R, Budkowska A: Nonenveloped nucleocapsids of hepatitis $C$ virus in the serum of infected patients. J Virol 2001;75:8240-8250.
0 Pietschmann T, Kaul A, Koutsoudakis G, Shavinskaya A, Kallis S, Steinmann E, Abid K, Negro F, Dreux M, Cosset FL, Bartenschlager R: Construction and characterization of infectious intragenotypic and intergenotypic hepatitis $\mathrm{C}$ virus chimeras. Proc Natl Acad Sci USA 2006;103:74087413.

31 Schuttler CG, Thomas C, Discher T, Friese G, Lohmeyer J, Schuster R, Schaefer S, Gerlich WH: Variable ratio of hepatitis $\mathrm{C}$ virus RNA to viral core antigen in patient sera. J Clin Microbiol 2004;42:1977-1981.

32 Tanaka E, Kiyosawa K, Matsumoto A, Kashiwakuma T, Hasegawa A, Mori H, Yanagihara O, Ohta Y: Serum levels of hepatitis C virus core protein in patients with chronic hepatitis $\mathrm{C}$ treated with interferon alfa. Hepatology 1996;23:1330-1333.

33 Nagao Y, Sata M, Itoh K, Tanikawa K, Kameyama T: Quantitative analysis of HCV RNA and genotype in patients with chronic hepatitis $\mathrm{C}$ accompanied by oral lichen planus. Eur J Clin Invest 1996;26:495-498.
34 Arase Y, Ikeda K, Chayama K, Murashima N, Tsubota A, Suzuki Y, Saitoh S, Kobayashi M, Kobayashi M, Suzuki F, Kumada H: Fluctuation patterns of HCV-RNA serum level in patients with chronic hepatitis C. J Gastroenterol 2000;35:221-225.

35 Gale M Jr, Foy EM: Evasion of intracellular host defence by hepatitis C virus. Nature 2005;436:939-945.

36 Saito T, Owen DM, Jiang F, Marcotrigiano J, Gale M: Innate immunity induced by composition-dependent RIG-I recognition of hepatitis C virus RNA. Nature 2008;454: 523-527.

37 Kobayashi M, Yoshiki R, Sakabe J, Kabashima K, Nakamura M, Tokura Y: Expression of Toll-like receptor 2, NOD2 and dectin-1 and stimulatory effects of their ligands and histamine in normal human keratinocytes. Br J Dermatol 2009;160:297-304. 